\title{
Resistance rather than tolerance explains survival of savannah honeybees (Apis mellifera scutellata) to infestation by the parasitic mite Varroa destructor
}

\author{
URSULA STRAUSS $^{1}$, VINCENT DIETEMANN ${ }^{1,2}$, HANNELIE HUMAN $^{1}$, ROBIN M. CREWE ${ }^{1}$ and \\ CHRISTIAN W.W. PIRK ${ }^{1 *}$
}

\footnotetext{
${ }^{1}$ Social Insect Research Group, Department of Zoology and Entomology, University of Pretoria, Private Bag X20, Hatfield, Pretoria, South Africa 0028.

${ }^{2}$ Agroscope, Swiss Bee Research Centre, 3003 Bern, Switzerland.

*Corresponding author: cwwpirk@zoology.up.ac.za

Fax: (+27) 0123625242

Tel: (+27) 0124204616

Postal Address: Social Insect Research Group, Department of Zoology and Entomology, University of Pretoria, Private Bag X20, Hatfield, Pretoria, South Africa 0028.
}

Short title: Parasite resistance in the savannah honeybee

\section{SUMMARY}

Varroa destructor is considered the most damaging parasite affecting honeybees (Apis mellifera L.). However, some honeybee populations such as the savannah honeybee (A. m. scutellata) can survive mite infestation without treatment. It is unclear if survival is due to resistance mechanisms decreasing parasite reproduction or to tolerance mechanisms decreasing the detrimental effects of mites on the host. This study investigates both aspects by quantifying the reproductive output of $V$. destructor and its physiological costs at the individual host level. Costs measured were not consistently lower when compared to susceptible honeybee populations, indicating a lack of tolerance. In contrast, reproduction of $V$. destructor mites was distinctly lower than in susceptible populations. There was a higher proportion of infertile individuals and the reproductive success of fertile mites was lower than measured to date, even in surviving populations. Our results suggest that survival of savannah honeybees is based on resistance rather than tolerance to this parasite. We identified traits that may be useful for breeding programs aimed at increasing the survival of susceptible populations. African honeybees may have benefited from a lack of human interference, allowing natural selection to shape a population of honeybees that is more resistant to Varroa mite infestation. 
Keywords: Apis mellifera scutellata, Varroa destructor, resistance, tolerance, physiological cost, mite, reproduction

\section{KEY FINDINGS}

Varroa destructor parasitism negatively affected physiological parameters of savannah honeybees

The high costs of parasitism indicate the absence of tolerance mechanisms

Low mite reproduction indicates resistance of this population

\section{INTRODUCTION}

Varroa destructor (Acari: Varroidae) is a haemolymph feeding parasitic mite of the honeybee (Apis spp.) that has been implicated in global colony losses (Rosenkranz et al. 2010). Mites can either be found on adults or inside cells containing developing brood (Donzé and Guerin, 1994). Of all honeybee life stages, pupae are the most exposed to damage as a result of prolonged mite feeding during development (Rosenkranz et al. 2010). Damage caused by Varroa mites during feeding on individuals has been reported in honeybees in Europe and the Americas, with the most pronounced effects being a reduction in the weight, water content, haemolymph protein content, haemolymph volume, carbohydrate titre, hypopharyngeal gland development and ultimately the lifespan (De Jong et al. 1982; De Jong and De Jong, 1983; Glinski and Jarosz, 1984; Weinberg and Madel, 1985; Schneider and Drescher, 1987; Bowen-Walker and Gunn, 2001; Duay, 2002; Duay et al. 2003; Amdam et al. 2004; Contzen et al. 2004; Yang and CoxFoster, 2007; Pinto et al. 2011; Annoscia et al. 2012; van Dooremalen et al. 2012).

In addition to the direct physiological damage caused by feeding, Varroa mites can transmit several viruses and other pathogens (e.g. bacteria and fungi) to honeybees (Strick and Madel, 1988; Glinski and Jarosz, 1992; Liu, 1996; de Miranda et al. 2013; McMenamin and Genersch, 2015) that can negatively affect the individual honeybee and possibly the whole colony. As a result, beekeepers in most countries have to treat their colonies annually to ensure their survival (Rosenkranz et al. 2010). However, some honeybee populations survive mite infestations without chemical treatment (De Jong and Soares, 1997; Kefuss et al. 2004; Fries et 
al. 2006; Le Conte et al. 2007; Seeley 2007; Locke and Fries, 2011; Locke et al. 2012; Seeley et al. 2015). It is not yet clear whether their survival is due to tolerance that limits the detrimental effects of parasitism on the host or exclusively to resistance mechanisms reducing the fitness of the parasites (Råberg et al. 2007, 2009).

Since wild colonies cannot be treated, wild populations of European A. mellifera have, with a few exceptions, been eradicated by the invasive mite (Seeley et al. 2015). Such negative effects could result in significant selection among colonies exposed to the mites, especially in honeybee populations that are not being managed by beekeepers, e.g. the wild population in Africa (Dietemann et al. 2009; Pirk et al. 2014). In South Africa, the presence of Varroa mites was first recorded in savannah (A. m. scutellata) and Cape (A. m. capensis) honeybee colonies in the late 1990's (Allsopp, 1997, 2006; Martin and Kryger, 2002). It has been suggested that in both South African sub-species there has been selection among colonies for survival to mite infestation. In A. m. capensis, the short post-capping stage (Moritz, 1985), grooming behaviour (Moritz and Mautz, 1990) and the removal of mites through hygienic behaviour are likely explanations for colony survival (Allsopp, 2006). In A. m. scutellata colonies, survival has been attributed to reduced Varroa population growth (Strauss et al. 2015) and the low prevalence of viruses (Strauss et al. 2013).

In order to gain a better insight into the factors that contribute to colony survival in A. $m$. scutellata, we investigated the physiological effects of the parasite at the individual host level. We assessed the degree of tolerance of uninfested and mite infested individuals by estimating the physiological costs of parasitism on weight, water, lipid, and protein content of individuals. The fertility, fecundity and reproductive success of mites were similarly compared to determine resistance to the parasite. Since Varroa mites reproduce on drones and workers of A. mellifera (Rosenkranz et al. 2010), we considered brood of both sexes. Drones are of particular interest since variation in physiological parameters, such as weight have direct effects on flight ability and sperm quantity (Jarolimek and Otis, 2001; Schlüns et al. 2003). Indeed, male competition appears particularly high in African honeybee populations (Wallberg et al. 2014). Slight variations in the damage caused by parasitism can have large and direct effects on their competitiveness and hence on their fitness (Jandricic and Otis, 2003). Measurement of the damage caused to individuals and of the reproductive success of the Varroa mite in savannah honeybee colonies allows for a better understanding of the various ways survival to $V$. destructor 
develops in honeybee populations. This knowledge is crucial to develop programs aimed at the sustainable mitigation of losses caused by this parasite (Dietemann et al. 2012). In addition, investigating Varroa mites in the presence of a potentially resistant and/or tolerant honeybee population like the one in South Africa will improve our general understanding of this hostparasite interaction.

\section{MATERIALS AND METHODS}

\section{Collection of honeybees}

Queenright honeybee (A. m. scutellata) colonies situated at the Experimental Farm of the University of Pretoria, South Africa were used in this study. These colonies were trapped in the wild and were never treated against Varroa mites. Drone combs were mainly collected during spring, and on some occasions during autumn and winter. Worker combs, on the other hand, were mostly collected during autumn and winter and in some cases during spring and summer. In order to reduce disturbance triggered absconding of the colonies, combs with capped brood were removed from the colonies and placed in an incubator (Labcon Model LTIE, South Africa) at $34^{\circ} \mathrm{C}$ until a sufficient number of samples were collected. Drone and worker comb were kept for $2.9 \pm 0.4$ and $3.0 \pm 2.1$ days, respectively, in the incubator. The number of days brood was kept in the incubator did not affect mite reproduction. For drones, $35 \pm 25$ (mean \pm SD) cells in each of 13 colonies and for workers $100 \pm 0$ cells in each of 15 colonies were examined for the presence of adult Varroa mites and their offspring. Only cells in which individuals just started to chew through the wax capping were used to prevent any mites from escaping before they could be counted. Thus, only honeybees that were physically able to emerge from their cells were included. We used individuals at the time of emergence, because this encompasses the whole period during which Varroa mites feed on their hosts and reproduce. Opening the cells before emergence would have reduced the extent of damage caused by these mites and biased the measure of their reproductive output. The observed number of honeybees with deformed wings or no wings at emergence was recorded. 
Measures of physiological costs of parasitism in emerging drones and workers

The weight, water, lipid, and protein content of Varroa infested and uninfested drones and workers was measured to quantify the physiological cost of parasitism by $V$. destructor. Following collection (as described above), individual drones $(n=452)$ and workers $(n=1500)$ were weighed (Mettler Toledo MS204S, Switzerland) to the nearest $0.1 \mathrm{mg}$, placed in Eppendorf tubes and stored in the freezer $\left(-20^{\circ} \mathrm{C}\right)$ until analysis. To measure the water content, all the drones and workers were transferred to 24 well cell culture plates (Thermo Fisher Scientific, Rochester, NY, USA) and dried in an incubator (Memmert HCP 108, GmbH + Co.KG, Schwabach, Germany) at $60{ }^{\circ} \mathrm{C}$ until constant mass was reached. In order to determine the water content of each drone and worker, the final dry weight was subtracted from the original wet weight. The dried honeybees were placed in the freezer $\left(-20{ }^{\circ} \mathrm{C}\right)$ until the lipid and protein content was measured.

For lipid and protein quantification, the methods of Human et al. (2014) were used. The legs and wings of drones ( $83<n<85$ from 13 colonies) and workers ( $n=88$ from 15 colonies) were removed, and the individuals were weighed again to obtain dry weight without legs and wings. Briefly, for lipid analysis, $2 \mathrm{ml}$ and $1 \mathrm{ml}$ of Folch's reagent (2:1 chloroform:methanol) was added to drones and workers, respectively, once every 24 hours for three days in a fume hood. Heavy duty household foil was used to cover the vials after the first two washes and after the last wash the foil was removed to allow the reagent to evaporate. Twenty four hours after the last wash, drones and workers were placed into an incubator (Memmert HCP 108, GmbH + Co.KG, Schwabach, Germany) at $60{ }^{\circ} \mathrm{C}$ to dry for three days. Drones and workers were then weighed (Mettler Toledo MS204S, Switzerland) again to determine their dry weight after lipid removal by the reagent.

For protein analysis, drones and workers were individually homogenised in a lysis buffer (40 mM Tris: pH 7.6, 7M Urea, 2\% (v/v) Triton X-100 and SIGMAFAST Protease Inhibitor tablets) (300 $\mu 1$ and $200 \mu 1$ per drone and worker, respectively) using pestles. Samples were sonicated for 30 minutes. Following this, samples were centrifuged for 10 minutes at $12000 \mathrm{~g}$, the supernatant was collected from each tube and centrifuged for an additional 5 minutes at $12000 \mathrm{~g}$. The supernatants were then collected and diluted 50 (drones) and 20 (workers) fold in a re-suspension buffer (100 mM Tris: $\mathrm{pH}$ 7.6). The total protein content of drones and workers was determined using the Bradford method and the absorbance of samples and standards (Bovine 
serum albumin protein standard, Sigma-Aldrich) was measured at $595 \mathrm{~nm}$ using a plate reader (Biotek Eon; Analytical and Diagnostic Products, Johannesburg, South Africa) (Bradford, 1976).

The weight, water, lipid, and protein content of newly emerged drones and workers (uninfested or infested with foundress mites) were compared between the following conditions: 1) Drones/workers not parasitised by Varroa mites 2) Drones/workers parasitised by 1 foundress 3) Drones/workers parasitised by 2-3 foundresses 4) Drones/workers parasitised by $\geq 4$ foundresses. We chose these categories to allow for a comparison with previous studies. In addition, the relationship of these physiological parameters to the number of foundresses and their offspring was investigated. Cells in which dead foundresses were found were included in our analyses under the assumption that they had fed for an undetermined time before death and therefore had an effect on the physiology of the host.

\section{Assessment of Varroa mite reproduction in drone and worker brood}

In order to quantify Varroa mite reproduction, the number of foundresses, mature daughter mites, immature daughter mites and males were counted in each infested cell. The following parameters were recorded: infertility (live and dead foundresses with no offspring), fertility (production of offspring), fecundity (number of offspring produced), number of mature daughters, and presence (alive and dead) or absence of adult males (Dietemann et al. 2013). Foundresses were distinguished from mature daughters by their darker colouration (Dietemann et al. 2013), which can be a reliable distinction in some African honeybee sub-species due to the short post-capping time (Moritz, 1985). Cells containing one foundress were considered in determining Varroa reproductive success. Reproductive success was defined by the simultaneous presence of one live mature daughter and one live adult male in a cell (Locke et al. 2012). Multiply infested cells that contained one or more, but not only dead foundresses, were pooled with cells where all foundresses were alive. In multiply infested cells, foundresses with no offspring were considered to be infertile.

\section{Statistical analysis}

Statistical analysis was performed using STATISTICA 64 Version 12. In order to examine whether the extent of the physiological effects measured correlated with the number of foundress 
mites as well as the total number of mites (foundresses and their offspring), a Pearson or Spearman Rank Order correlation (depending on whether the data were normally distributed or not) was performed. A Kruskal-Wallis ANOVA with multiple comparisons of mean ranks for all groups was done to examine differences in each of the physiological parameters between individuals parasitised by $0,1,2-3$ and 4 or more foundresses. A Mann-Whitney $U$ Test was performed to test for differences in the number of mature daughters and total number of offspring produced in drone versus worker cells. In order to examine the differences in the number of mite offspring and mated daughters produced per cell and per foundress in drone and worker cells, a Kruskal-Wallis ANOVA with multiple comparisons of mean ranks for all groups was performed.

\section{RESULTS}

Effect of Varroa mite infestation on the physiological parameters of honeybees

\section{Drones}

Significant differences (weight decreased with an increase in mite number) were found between the weight of drones infested with 0 and $1\left(H_{3,452}=48.73, P<0.05\right), 0$ and $2-3\left(H_{3,452}=48.73, P\right.$ $<0.001)$ and 0 and $\geq 4\left(H_{3,452}=48.73, P<0.001\right)$ foundresses (Fig. 1). Similarly, the water content of drones was significantly different between individuals infested with 0 and $1\left(H_{3,452}=\right.$ 62.21, $P<0.05), 0$ and $2-3\left(H_{3,452}=62.21, P<0.001\right)$ and 0 and $\geq 4\left(H_{3,452}=62.21, P<0.001\right)$ foundresses. No significant differences were found in drone lipid $\left(H_{3,84}=0.73, P>0.87\right)$ and protein $\left(H_{3,85}=3.10, P>0.38\right)$ content when each of the groups were compared.

There was a significant, but weak negative correlation in drone weight $(n=452, r=-$ $0.33, P<0.05)$ and water content $(n=452, r=-0.37, P<0.05)$ with an increase in the number of foundresses. There was no correlation between the lipid $(n=83, r=0.02, P>0.05)$ or protein $(n$ $=85, r=-0.11, P>0.30)$ content of drones and the number of foundresses. When considering the total number of infesting mites, including foundresses and offspring, the correlation with weight $(n=452, r=-0.33, P<0.0001)$ and water content $(n=452, r=-0.37, P<0.0001)$ of drones was also significant and weakly negative. For each additional mite, a weight loss of 2.8 
$\mathrm{mg}(1.2 \%$ of the weight of an uninfested drone) was estimated from the correlation equation. There was no correlation between the total number of mites and the lipid $(n=84, r=0.01, P>$ $0.95)$ and protein $(n=85, r=-0.12, P>0.27)$ content of drones.

\section{Workers}

The weight of workers was significantly different (weight decreased as mite number increased) between cells infested with 0 and $1\left(H_{2,1500}=199.50, P<0.001\right)$, as well as 0 and $2-3\left(H_{2,1500}=\right.$ 199.50, $P<0.001$ ) foundresses (Fig. 1). Significant differences were also found in the water content of workers infested with 0 and $1\left(H_{2,1500}=215.86, P<0.001\right)$, as well as 0 and 2-3 $\left(H_{2,1500}=215.86, P<0.001\right)$ foundresses. The lipid $\left(H_{2,88}=3.74, P>0.15\right)$ and protein $\left(H_{2,88}=\right.$ $4.70, P>0.10)$ content of workers was not significantly different between the various groups.

The weight $(n=1500, r=-0.36, P<0.05)$ and water content $(n=1500, r=-0.38, P<$ 0.05) of workers were significantly but weakly negatively correlated with an increase in the number of foundresses. This was not the case for lipid ( $n=88, r=0.08, P>0.44$ ) or protein content $(n=88, r=-0.21, P>0.05)$.

The weight $(n=1500, r=-0.36, P<0.05)$, water $(n=1500, r=-0.38, P<0.05)$ and protein $(n=88, r=-0.24, P<0.05)$ content of workers decreased significantly, but weakly, as the total number of mites (foundresses and their offspring) increased. For each additional mite, a weight loss of $2.8 \mathrm{mg}$ ( $3.3 \%$ of the weight of an uninfested worker) could be estimated from the regression equation. No correlation was found between the total number of mites and the lipid ( $n$ $=88, r=0.05, P>0.62)$ content of workers.

\section{Assessment of Varroa mite reproduction in drone and worker brood}

\section{Varroa infestation rates}

In total for drones, 452 cells were opened of which 335 cells $(74.1 \%)$ were not infested, 42 cells $(9.3 \%)$ were infested with one foundress, 27 cells (6.0\%) were infested with 2-3 foundresses and 48 cells $(10.6 \%)$ were infested with $\geq 4$ foundresses. Therefore, based on a $25.9 \%$ overall infestation rate of the cells, one can calculate the probability of a mite being found in a cell by solving the $4^{\text {th }}$ order equation $\left((1) 0.257=p_{d}+p_{d}{ }^{2}+p_{d}{ }^{3}+p_{d}{ }^{4}\right)$ focusing on up to 4 mites per 

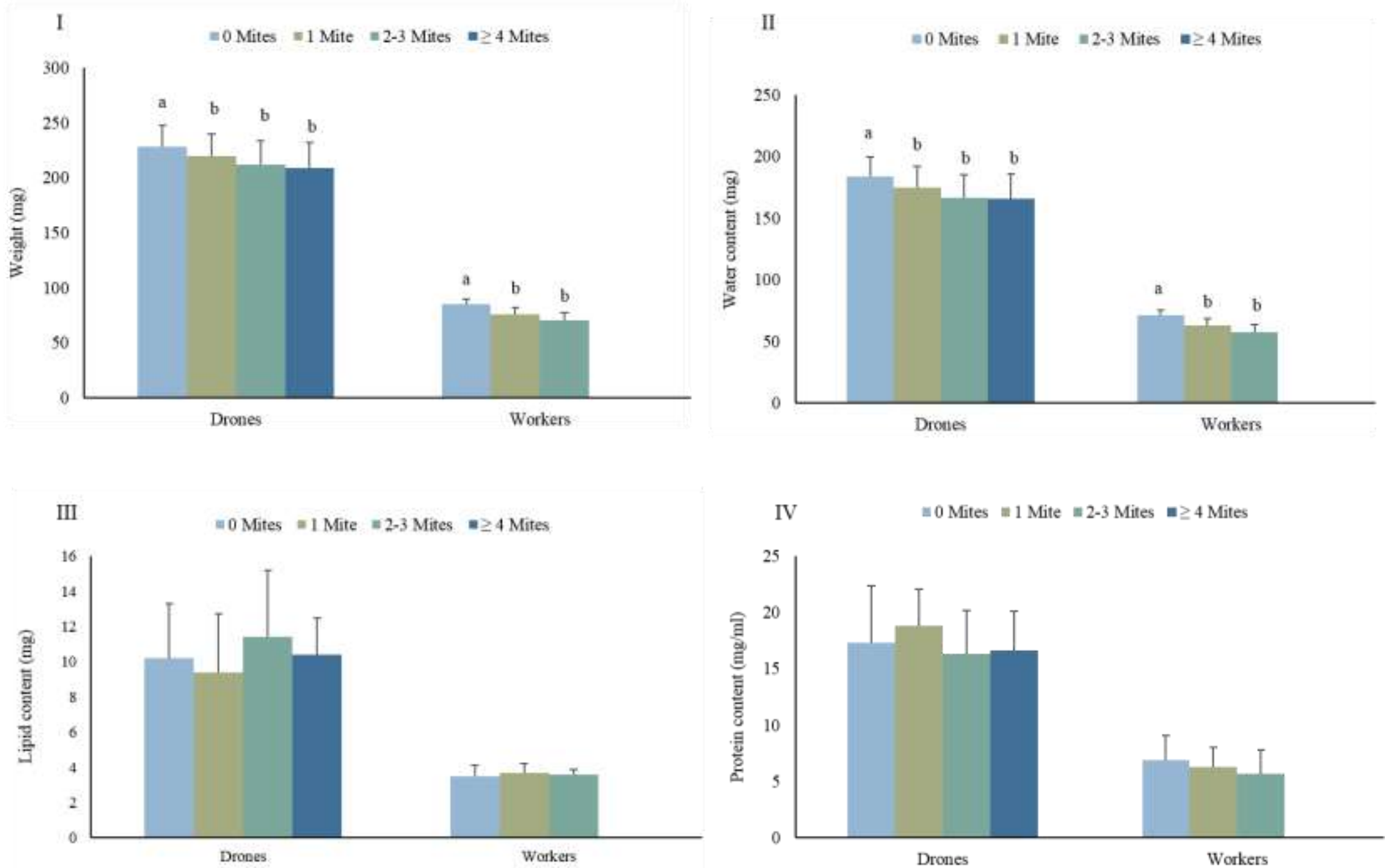

Fig. 1. Physiological parameters (mean $\pm \mathrm{SD}$ ) of Apis mellifera scutellata drones and workers affected by foundress (Varroa destructor) mites. I: Weight (mg); II: Water content (mg); III: Lipid content (mg); IV: Protein content (mg/ml). Significant differences (Kruskal-Wallis ANOVA; $P<$ 0.05 , with multiple comparisons of mean ranks for all groups) of physiological parameters for each of the Varroa groups are denoted by different letters. No letters indicate no significant differences. 
Table 1. Weight loss (\%) of mite infested drones and workers compared to uninfested individuals in this study, as well as in the literature

1 Mite 1-3 Mites 2-3 Mites $\geq 4$ Mites 1-11 Mites $\begin{aligned} & \text { Honeybee } \\ & \text { origin }\end{aligned}$ References

\section{Drones}

3.7

\section{2 \\ 3.1}

11.3
7.3

16.8

12

9.6
14.1

18.3
8.6

4

14

4.1

African

European

European

\begin{abstract}
African
\end{abstract}
This study

This study

Schneider and Drescher, 1987

Duay et al. 2003

\section{Workers}

10.2

$\begin{array}{lll} & 16.8 & \\ 12 & & \\ 9.6 & & 21.6 \\ & 11.8 & 21.2\end{array}$

African

African

European

*Africanised

*European
This study

This study

Schneider and Drescher, 1987

De Jong et al. 1982

Bowen-Walker and Gunn, 2001

*Number of foundresses was considered except in these two studies where foundresses and deutonymphs were pooled. However, our data show that individual offspring accounts for a maximum of $2 \%$ of the decrease in weight due to infestation, allowing for a meaningful comparison of these figures.

cell for simplicity sake. With $\mathrm{p}_{\mathrm{d}}$ being the probability that a mite enters a drone cell. The only positive real solution of equation 1 is $p_{d}=0.206$, which means that one would expect that $5.2 \%$ $\left(=0.206^{2}+0.206^{3}\right)$ of the cells have $2-3$ mites by chance but only $0.2 \%\left(=0.206^{4}\right)$ of the cells should have 4 or more mites which is lower than the observed infestation rate of $10.6 \%$.

In total, 1500 worker cells were opened, of which 1386 (92.4\%) were not infested, 84 (5.6\%) were infested with one foundress and 30 cells (2.0\%) were infested with 2-3 foundresses. No worker cells were infested with $\geq 4$ foundresses. Since no worker cells with 4 or more mites were observed, one would have to solve the following $3^{\text {rd }}$ order equation: ((1) $0.076=\mathrm{p}_{\mathrm{w}}+\mathrm{p}_{\mathrm{w}}{ }^{2}+$ $\mathrm{p}_{\mathrm{w}}{ }^{3}$ ) with $\mathrm{p}_{\mathrm{w}}$ being the probability that a mite enters a worker cell. The only positive real solution of equation 2 is $\mathrm{p}_{\mathrm{w}}=0.0706$, therefore the expected frequency of cells with 2-3 mites should be 
$0.5 \%$ which is 4 times lower than the observed value of $2 \%$. The differences between the expected and observed values show that the distribution of the mites is not random but clumped.

\section{Reproduction in singly infested cells}

In drones, a single foundress was found in 42 of the 452 cells (9\%) examined. In 8 of the 42 (19\%) singly infested cells the foundress died. In 7 of these cells there was no reproduction and

therefore these foundresses were considered to be infertile. In the remaining cell, there was reproduction and this foundress was regarded as fertile (Table 2). Varroa mites produced at least one offspring in 20 out of the 42 cells (47\%) and thus 20 cells were used to assess reproductive success (Table 2).

Of the 1500 worker cells examined, 84 (5.6\%) were infested with one foundress. Dead foundresses were observed in 6 out of the 84 cells $(7 \%)$. No reproduction occurred in these cells and as a result these foundresses were classified as infertile (Table 2). Varroa mites reproduced in 59 out of the 84 cells (70\%) and therefore 59 cells were used to measure reproductive success (Table 2).

\section{Reproduction in cells containing 2-3 foundresses}

In 5 out of 27 (19\%) drone cells infested with 2-3 live foundresses there was no reproduction. In total (considering all cells with foundresses where reproduction occurred) 49 offspring were found with $2.2 \pm 0.8$ offspring produced per cell (Fig. 2).

In worker cells, Varroa mite reproduction occurred in all 30 cells infested with 2-3 foundresses. A total (considering all cells with foundresses where reproduction occurred) of 90 offspring were produced, with $3.0 \pm 1.3$ offspring produced per cell (Fig. 3).

\section{Reproduction in cells containing $\geq 4$ foundresses}

The highest number of foundresses found in one drone cell was 12 , and on average $5.8 \pm 2.2$ foundresses were found per cell infested by 4 or more mites. In 7 out of 48 cells (15\%) there was no mite reproduction. In total (considering all cells with foundresses where reproduction 
occurred), 94 offspring were found in 41 cells and on average $2.3 \pm 1.2$ offspring were produced per cell (Fig. 2).

Reproductive output per cell and per foundress in singly versus multiply infested cells

A significantly higher number of offspring per foundress was produced in drone cells infested with 1 foundress compared to $\geq 4$ foundresses $\left(H_{2,83}=50.23, P<0.001\right)$ as well as in cells with 2-3 foundresses compared to $\geq 4$ foundresses $\left(H_{2,83}=50.23, P<0.001\right.$; Fig. 2$)$. The number of mated daughters produced increased significantly $\left(H_{2,83}=11.06, P<0.05\right)$ per drone cell as the number of foundresses increased.

In worker cells, a significantly $\left(H_{1,89}=10.89, P<0.01\right)$ higher number of offspring were produced per foundress in singly infested cells (Fig. 3). In terms of the number of offspring produced per cell, no significant differences were observed between singly and multiply infested worker brood $\left(H_{1,89}=0.46, P>0.50\right)$. The same was true for the number of mated daughters produced per cell $\left(H_{1,89}=3.40, P>0.07\right)$ and per mite $\left(H_{1,89}=3.40, P>0.07\right)$. A comparison of the total number of offspring and daughter mites produced in drone versus worker cells is presented in Table 4.

\section{Presence of deformed drones and workers}

The percentage of deformed drones infested with $0,1,2-3$ and $\geq 4$ foundresses was $0,7.1,7.4$ and $6.3 \%$, respectively. The percentage of deformed workers infested with 0,1 and 2-3 foundresses, was $0.3,2.4$, and $13.3 \%$, respectively. 
Table 2. Reproduction of Varroa destructor in Apis mellifera scutellata drone and worker cells infested with one foundress

\begin{tabular}{|c|c|c|}
\hline Cell status & Drones $(n=42)$ & Workers $(n=84)$ \\
\hline Foundresses (alive) & $81 \%$ & $93 \%$ \\
\hline Foundresses (dead) & $19 \%$ & $7 \%$ \\
\hline Infertile & $52 \%$ & $30 \%$ \\
\hline Fertile & $48 \%$ & $70 \%$ \\
\hline \multicolumn{3}{|l|}{ All foundresses (fertile and infertile) } \\
\hline Adult males only (alive) & $7 \%$ & $10 \%$ \\
\hline Adult males only (dead) & $2 \%$ & $5 \%$ \\
\hline Mated adult daughters (adult daughter and adult male) & $2 \%$ & $19 \%$ \\
\hline Unmated daughters (adult daughter and adult male dead) & $2 \%$ & $0 \%$ \\
\hline Unmated daughters (adult male dead) & $5 \%$ & $4 \%$ \\
\hline Unmated daughters (adult male missing) & $10 \%$ & $11 \%$ \\
\hline Immature daughters and mature male & $7 \%$ & $11 \%$ \\
\hline Immature daughters and no male & $12 \%$ & $12 \%$ \\
\hline Number of offspring produced (mean $\pm \mathrm{SD}$ ) & $1.0 \pm 1.3$ & $1.7 \pm 1.5$ \\
\hline $\begin{array}{l}\text { Average number }( \pm \mathrm{SD}) \text { of mated daughters } \\
\text { (reproductive success) per cell }\end{array}$ & $0.0 \pm 0.2$ & $0.3 \pm 0.7$ \\
\hline Fertile foundresses only & $(n=20$ cells $)$ & $(n=59$ cells $)$ \\
\hline Adult males only (alive) & $15 \%$ & $14 \%$ \\
\hline Adult males only (dead) & $5 \%$ & $7 \%$ \\
\hline Mated adult daughters (adult daughter and adult male) & $5 \%$ & $27 \%$ \\
\hline Unmated daughters (adult daughter and adult male dead) & $5 \%$ & $0 \%$ \\
\hline Unmated daughters (adult male dead) & $10 \%$ & $5 \%$ \\
\hline Unmated daughters (adult male missing) & $20 \%$ & $15 \%$ \\
\hline Immature daughters and mature male & $15 \%$ & $15 \%$ \\
\hline Immature daughters and no male & $25 \%$ & $17 \%$ \\
\hline Number of offspring produced (mean $\pm \mathrm{SD}$ ) & $2.0 \pm 1.2$ & $2.4 \pm 1.2$ \\
\hline $\begin{array}{l}\text { Average number }( \pm \mathrm{SD}) \text { of mated daughters } \\
\text { (reproductive success) per cell }\end{array}$ & $0.1 \pm 0.4$ & $0.4 \pm 0.7$ \\
\hline
\end{tabular}


Table 3. A comparison of reproductive parameters between savannah (Apis mellifera scutellata), Africanised and European honeybees in drone and worker cells naturally infested with one foundress. All singly infested cells were considered (fertile and infertile foundresses)

\begin{tabular}{|c|c|c|c|c|c|c|c|c|c|c|}
\hline Honeybees & $\begin{array}{l}\text { Treated } \\
\text { against } \\
\text { mites }\end{array}$ & $\begin{array}{l}\text { Fertility } \\
(\%)\end{array}$ & $\begin{array}{l}\text { Infertility } \\
(\%)\end{array}$ & $\begin{array}{l}\text { *Mated } \\
\text { daughters } \\
(\%)\end{array}$ & $\begin{array}{l}\text { *Unmated } \\
\text { daughters } \\
(\%)\end{array}$ & $\begin{array}{l}\text { Males } \\
\text { only } \\
(\%)\end{array}$ & $\begin{array}{l}\text { Fecundity } \\
(\text { mean } \pm \mathrm{SD})\end{array}$ & $\begin{array}{l}\text { No. of mated } \\
\text { daughters } \\
(\text { mean } \pm \mathrm{SD})\end{array}$ & $\begin{array}{l}\text { Developmental } \\
\text { stage/hours } \\
\text { post-capping }\end{array}$ & References \\
\hline
\end{tabular}

\section{Drones}

\begin{tabular}{|c|c|c|c|c|c|c|c|c|c|c|}
\hline Savannah & No & 48 & 52 & 2 & 36 & 9 & $1.0 \pm 1.3$ & $0.0 \pm 0.2$ & Emerging & This study \\
\hline & & & & & & & $3.4 \pm 0.8$ & & & $* *$ This study \\
\hline Savannah & No & 98 & 2 & 59 & 13 & 20 & $4.9 \pm 1.0$ & $2.2 \pm ?$ & $\begin{array}{l}\text { Cells sealed } \\
\geq 200 \text { hours }\end{array}$ & Martin and Kryger, 2002 \\
\hline Africanised & No & 93 & 7 & 65 & 19 & 9 & $4.0 \pm 1.9$ & $2.1 \pm 1.9$ & $\begin{array}{l}\text { Cells sealed } \\
\geq 240 \text { hours }\end{array}$ & Calderón et al. 2012 \\
\hline European & Yes & 97 & 3 & 63 & 15 & 14 & $4.1 \pm ?$ & $1.9-2.1 \pm ?$ & $\begin{array}{l}\text { Cells sealed } \\
\geq 322 \text { hours }\end{array}$ & $* * *$ Martin, $1995 \mathrm{a}$ \\
\hline Workers & & & & & & & & & & \\
\hline Savannah & No & 70 & 30 & 19 & 38 & 15 & $\begin{array}{l}1.7 \pm 1.5 \\
3.5 \pm 0.6\end{array}$ & $0.3 \pm 0.7$ & Emerging & $\begin{array}{l}\text { This study } \\
* * \text { This study }\end{array}$ \\
\hline Savannah & No & 87 & 13 & 51 & 15 & 15 & $4.5 \pm 0.7$ & $0.9 \pm ?$ & Cells sealed $\geq$ & Martin and Kryger, 2002 \\
\hline
\end{tabular}


200 hours

\begin{tabular}{|c|c|c|c|c|c|c|c|c|c|c|}
\hline Africanised & No & 88 & 12 & 44 & 33 & 11 & $4.9 \pm 0.6$ & $0.7 \pm ?$ & $\begin{array}{l}\text { Close to } \\
\text { emergence }\end{array}$ & Medina and Martin, 1999 \\
\hline Africanised & No & 89 & 11 & 38 & 34 & 18 & $3.2 \pm 1.6$ & $0.5 \pm 0.8$ & $\begin{array}{l}\text { Cells sealed } \geq \\
240 \text { hours }\end{array}$ & Calderón et al. 2012 \\
\hline \multirow[t]{4}{*}{ European } & No & & & & & & $\begin{array}{l}3.1 \pm 0.1 \\
(\text { mean } \pm S E)\end{array}$ & & \multirow{4}{*}{$190<x<280 h$} & ****Locke and Fries, 201 \\
\hline & No & & & & & & $\begin{array}{l}3.7 \pm 0.1 \\
(\text { mean } \pm \mathrm{SE})\end{array}$ & & & Locke et al. 2012 \\
\hline & Yes & & & & & & $\begin{array}{l}4.1 \pm 0.0 \\
(\text { mean } \pm \text { SE })\end{array}$ & & & ****Locke and Fries, 201 \\
\hline & Yes & & & & & & $\begin{array}{l}4.3 \pm 0.1 \\
(\text { mean } \pm \mathrm{SE})\end{array}$ & & & Locke et al. 2012 \\
\hline
\end{tabular}

Methodology can differ between the studies cited. The number of offspring observed may be slightly overestimated compared to our results since mortality could have occurred, had the honeybee been allowed to emerge. For the other parameters measured, cells were opened late enough for valid comparisons to be made. '?' indicates that values are not available. *Live mature daughters are assumed to have mated when a live adult male was present in the cell. Daughters are assumed unmated when immature, dead or when the male was dead/missing. **Fecundity calculated in cells containing 3 or more offspring, to allow for a better comparison with Martin and Kryger (2002). ***Values as re-calculated by Martin and Kryger (2002). ****Only fertile foundresses were included in the fecundity assessment. 
Table 4. A comparison of the total number of offspring and total number of mature daughter mites (all daughters irrespective of whether male was absent/present) produced in drone and worker cells infested with 1, 2-3 foundresses and a combined number of foundresses (1-12). Data are presented for fertile foundresses as well as all foundresses (fertile and infertile)

\begin{tabular}{|c|c|c|c|c|c|c|c|c|c|}
\hline & \multicolumn{3}{|c|}{1 Foundress } & \multicolumn{3}{|c|}{ 2-3 Foundresses } & \multicolumn{3}{|c|}{ Combined number of foundresses $(1-12)$} \\
\hline & No. of cells & Total & $P$-value & No. of cells & Total & $P$-value & No. of cells & Total & $P$-value \\
\hline \multicolumn{10}{|l|}{ No. of offspring } \\
\hline \multirow[t]{2}{*}{ Fertile foundresses } & Drones $(n=20)$ & 40 & $P>0.2$ & Drones $(n=22)$ & 49 & $* P<0.05$ & Drones $(n=83)$ & 183 & $* P<0.05$ \\
\hline & Workers $(n=59)$ & 141 & & Workers $(n=30)$ & 90 & & Workers $(n=89)$ & 231 & \\
\hline \multirow[t]{2}{*}{ All foundresses } & Drones $(n=42)$ & 40 & $* P<0.05$ & Drones $(n=27)$ & 49 & $* P<0.05$ & Drones $(n=117)$ & 183 & $* P<0.05$ \\
\hline & Workers $(n=84)$ & 141 & & Workers $(n=30)$ & 90 & & Workers $(n=114)$ & 231 & \\
\hline \multicolumn{10}{|l|}{$\begin{array}{l}\text { No. of mature } \\
\text { daughters }\end{array}$} \\
\hline \multirow[t]{2}{*}{ Fertile foundresses } & Drones $(n=20)$ & 12 & $P>0.6$ & Drones $(n=22)$ & 24 & $P>0.1$ & Drones $(n=83)$ & 60 & $P>0.1$ \\
\hline & Workers $(n=59)$ & 42 & & Workers $(n=30)$ & 22 & & Workers $(n=89)$ & 64 & \\
\hline All foundresses & Drones $(n=42)$ & 12 & $P>0.2$ & Drones $(n=27)$ & 24 & $P>0.6$ & Drones $(n=117)$ & 60 & $P>0.7$ \\
\hline
\end{tabular}

\footnotetext{
* Significant differences: Mann-Whitney U Test, $P<0.05$.
} 


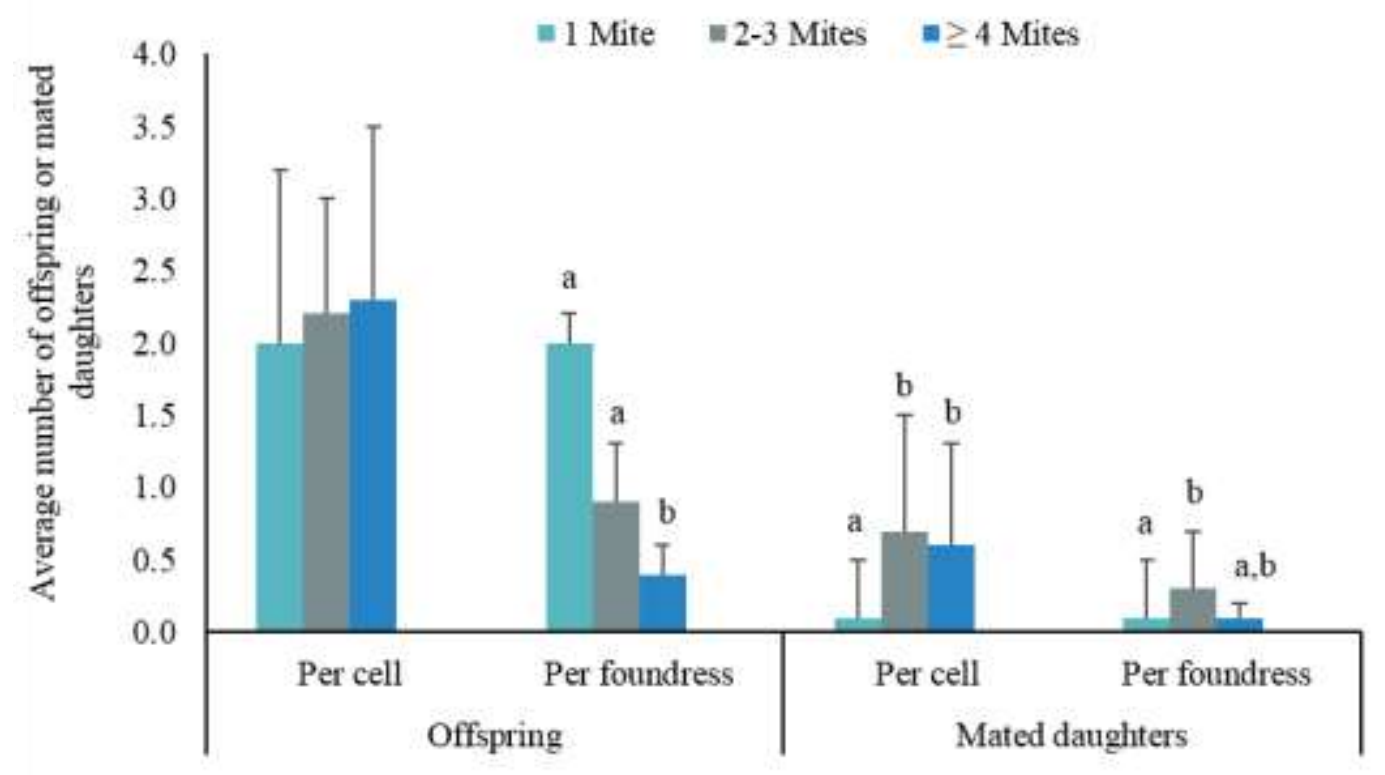

Fig. 2. The number of offspring and mated daughters (mean \pm SD) produced per cell and per foundress in drone brood parasitised by $1,2-3$ or $\geq 4$ foundresses (only fertile foundresses were considered). Significant differences (Kruskal-Wallis ANOVA; $P<0.05$, with multiple comparisons of mean ranks for all groups) are denoted by different letters for each category. No letters indicate no significant effects for each category.

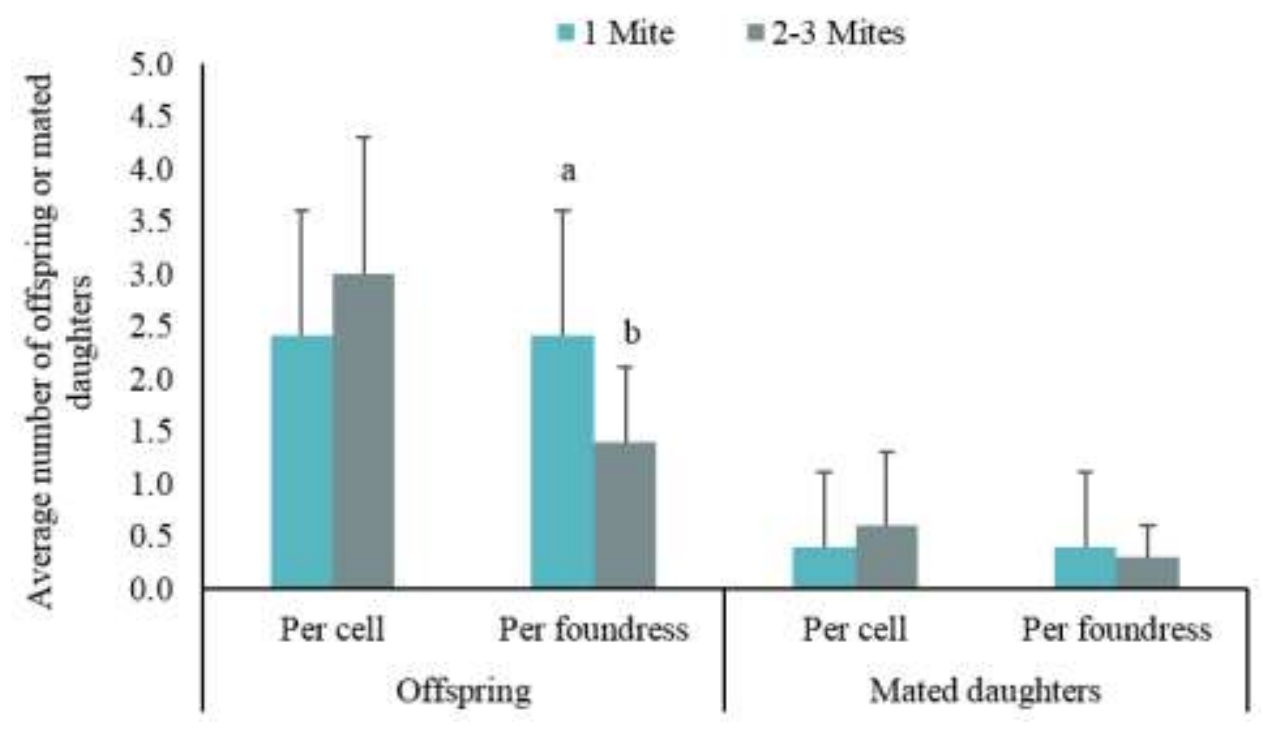

Fig. 3. The number of offspring and mated daughters (mean \pm SD) produced per cell and per foundress in worker brood parasitised by 1 or 2-3 foundresses (only fertile foundresses were considered). Significant differences (Kruskal-Wallis ANOVA; $P<0.05$, with multiple comparisons of mean ranks for all groups) are denoted by different letters for each category. No letters indicate no significant effects for each category. 


\section{DISCUSSION}

We provide the first report on the physiological costs of Varroa mite parasitism in an African honeybee sub-species, A. m. scutellata. The weight and water content of drones and workers of this population decreased significantly as the number of foundresses and the total number of mites (foundresses and their offspring) increased. Drone and worker lipid content was not affected by Varroa mites. The protein level of workers was significantly reduced, but only as the total number of mites increased. Mite infertility was $52 \%$ and $30 \%$ in drone and worker cells, respectively.

\section{Number of deformed honeybees}

Honeybees with wing deformities usually die shortly after emergence (Yang and Cox-Foster, 2007) and therefore the health of the colony may be negatively affected if a large number of deformed honeybees emerge that cannot contribute to the normal functioning of the colony (de Miranda and Genersch, 2010). In this study, only $7 \%$ of drones and $8 \%$ of workers were deformed when infested with one or more mites. We observed the highest percentage of physical deformity (no wings or deformed wings) in drones (7.4\%) and workers (13.3\%) infested with 2-3 foundresses. In Africanised honeybees, De Jong et al. (1982) showed that only 6\% of workers with mites were deformed, which is consistent with our results. In contrast, Marcangeli et al. (1992) found that $29 \%$ of European worker honeybees with one or more mites were deformed. Wing deformity is most often noticed in honeybees parasitised by Varroa mites that are capable of transmitting deformed wing virus (DWV) during pupal development (Gisder et al. 2009; de Miranda and Genersch, 2010). DWV has to replicate in the mite transmitting the virus with a high enough titre to produce honeybees with deformed wings (Gisder et al. 2009). However, DWV was shown to be absent from the population studied here and hence cannot be implicated in producing these deformities. It has recently been suggested that VDV-1, which was found in both honeybees and Varroa mites of our study population (Strauss et al. 2013) could also produce deformed wings (Zioni et al. 2011). The role of Varroa mites and their associated viruses in wing deformity in this A. $m$. scutellata population therefore needs to be investigated further. 


\section{Effect of Varroa parasitism on the physiological parameters of drones and workers}

Lipid levels measured in this study were slightly higher than was previously found for $A$. $m$. scutellata workers and other sub-species at emergence (Hrassnigg and Crailsheim, 2005 and references therein) most likely due to inter-population variation. Lipid levels of drones and workers were unaffected by Varroa mite parasitism and this is in agreement with what BowenWalker and Gunn (2001) found for newly emerged European workers. Significant differences between infested and uninfested individuals may have been too small to detect due to the low lipid levels at emergence as well as due to methodological constraints (Bowen-Walker and Gunn, 2001). The absence of differences in lipid contents between a susceptible honeybee population and A. m. scutellata does not allow a conclusion regarding the occurrence of tolerance in the latter.

In this and other studies, the weight of drones and workers decreased as the number of foundresses as well as the total number of mites increased (De Jong et al. 1982; Schneider and Drescher, 1987; Bowen-Walker and Gunn, 2001; Duay et al. 2003; Annoscia et al. 2012). A comparison between the degree of weight reduction between mite infested and uninfested individuals of surviving and susceptible honeybee populations is given in Table 1. Our results suggest a generally lower effect of mite parasitism on the weight of drones compared to these reported in the literature for susceptible honeybees. This is unexpected since African drones are smaller than their European counterparts and should thus suffer proportionally greater haemolymph loss (Bowen-Walker and Gunn, 2001) than larger individuals. A lower effect due to infestation by 1-3 mites described by Schneider and Drescher (1987) constitutes an exception to this trend and suggests that there is no consistent evidence for higher tolerance in $A$. $m$. scutellata. Similarly, the effect of parasitism on the weight of newly emerged workers in our study tended to be higher than that of susceptible European as well as surviving Africanised honeybees. Compared to European workers, African workers are smaller (Fletcher, 1978) and are expected to have suffered proportionally larger weight loss. The difference, however, was small with a loss of $3.3 \%$ body weight per mite in our study compared to approximately $3 \%$ reported by Bowen-Walker and Gunn (2001). A comparison of the data on worker weight loss, calculated from the slopes of a regression line obtained from Table 1 (data not shown), gave varying results. Compared to Schneider and Drescher (1987), A. m. scutellata can either be more 
or less tolerant due to insufficient details in the results, and seems more tolerant to infestations by Varroa mites in De Jong et al. (1982).

It has been suggested that the weight loss experienced by Varroa infested honeybees results from the loss of water due to the damage caused to the honeybee cuticle during mite feeding (Annoscia et al. 2012), and the depletion of haemolymph (Bowen-Walker and Gunn, 2001). In our study as well as in Bowen-Walker and Gunn (2001) and Annoscia et al. (2012), the water content of workers and drones decreased as the number of foundresses and total number of mites present increased. However, workers of $A$. $m$. scutellata lost a higher percentage of their body water ranging from $11.8 \%$ (one foundress present) to $18.8 \%$ for individual workers infested with 2-3 foundresses. A comparison of the data on the loss in the water content of workers, calculated from the slopes of a regression line (data not shown), showed that A. m. scutellata appears less tolerant than a susceptible population (Bowen-Walker and Gunn, 2001). For drones, we observed water loss of $4.8 \%$ in singly infested individuals and this number increased to $9.6 \%$ for multiply infested individuals. These results suggest that workers of $A$. $m$. scutellata are more affected by Varroa mite infestation than those of susceptible populations and therefore that no tolerance mechanism evolved to reduce the detrimental effects of mite feeding. There is limited information on the loss in water content of mite infested drones, and thus whether this $A$. $m$. scutellata drone population is tolerant or not requires further investigation.

A reduction in the total protein content of mite infested workers has been observed in purple eye pupae (Aronstein et al. 2012) and newly emerged honeybees (Yang and Cox-Foster, 2007). Other studies however, did not find any differences in the total protein content of mite infested versus uninfested drone pre-pupae (Źółtowska et al. 2005) and newly emerged workers (Aronstein et al. 2012). Similarly, in our study, the protein levels of drones were not influenced by the feeding activities of foundress mites or the total number of mites (foundresses and their offspring). In workers, protein levels were significantly reduced as the total number of mites in a cell increased, but not when only the number of foundresses was considered. Similar to the other physiological parameters measured, we do not find clear evidence for tolerance when the effect of parasitism on protein content of A. $m$. scutellata is considered.

Losses suffered during pupal development as a result of Varroa mite parasitism can affect some aspects of adult honeybee life. Varroa mites reduced the lifespan and flight ability of European worker honeybees (Schneider and Drescher, 1987; Kralj and Fuchs, 2006; Annoscia et 
al. 2012), while Varroa infested drones were found to produce less sperm and did not perform as well during flight (Duay et al. 2002). Alaux et al. (2011) and van Dooremalen et al. (2013) found that individuals that had been parasitised by Varroa mites and given pollen as adults were unable to compensate for the damage inflicted by mites during their pupal development, thus likely affecting their performance. Here we studied the physiological cost of parasitism to immature honeybees, but whether adults show a tolerance to infestations that could decrease the effect of parasitism by $V$. destructor requires further studies.

\section{Mite reproduction in singly infested cells}

Infertility or low reproductive success of the parasite could indicate host resistance (Rosenkranz and Engels, 1994; Rosenkranz, 1999; Locke and Fries, 2011; Locke et al. 2012). The proximate mechanism leading to low population growth can be the frequent occurrence of unmated daughter mites that enter brood cells even though they cannot reproduce (Martin et al. 1997). Alternatively, many female mites that mated also fail to reproduce (Martin et al. 1997; Kirrane et al. 2011; Frey et al. 2013), thereby adding to the proportion of infertile individuals. We found infertile mites in $52 \%$ of drone and $30 \%$ of worker brood (Table 2). In the same population of savannah honeybees investigated a decade earlier, Martin and Kryger (2002) found no offspring in $13 \%$ of worker cells and only in $2 \%$ of drone cells. Our results therefore suggest that the rate of Varroa mite reproductive failure has increased over time. Infertility rates are also higher than those reported for Varroa tolerant Cape honeybees, on which mites remained infertile in $26 \%$ of both worker and drone cells (Allsopp, 2006). This could reflect the effect of selection on savannah honeybee colonies that has resulted in a reduction of mite population growth. The infertility levels measured in this study were much higher compared to surviving and susceptible honeybee populations mentioned in Table 3. Our high infertility rates are not unusual, since infertility rates as high as 40-65\% (Ritter, 1993) and 60-90\% (Ruttner and Marx, 1984) have been reported in other surviving African and Africanised honeybees, respectively. In our study, the high level of mite infertility indicates a strong suppression of mite reproduction and hence high host resistance.

In A. m. scutellata, single fertile foundresses invading drone and worker cells produced $2.0 \pm 1.2$ and $2.4 \pm 1.2$ offspring, respectively. When considering all foundresses (including those that did not produce offspring at all), fecundity decreased to $1.0 \pm 1.3$ (drones) and $1.7 \pm$ 
1.5 (workers) offspring being produced per mite. This is much lower than in other surviving or susceptible populations for which fecundity, irrespective of host sex, is described (Table 3). However, similar and even lower fecundity rates have also been reported in surviving Africanised honeybees from Brazil (1.7 \pm 0.5 ) during the late 1980's (Carneiro et al. 2007). They found that, after twenty years, this number increased to $2.6 \pm 0.6$, thereby showing that this parameter can change over time. Fecundity rates in our study are also lower than previously reported for this population (Martin and Kryger, 2002). The low fecundity of mites measured in this study may be the cause of the slow rate at which mite populations grow in these colonies (Strauss et al. 2015).

Fecundity does not necessarily reflect reproductive success of a foundress. For fertile individuals to reproduce successfully during a reproductive cycle, they have to contribute at least one mature mated daughter to the mite population (Martin, 1994, 1995a). In this study, reproductive success was observed in $2 \%$ and $19 \%$ of infested drone and workers cells, respectively. In comparison to other studies (Table 3) this parameter confirms high resistance of A. m. scutellata to infestation by $V$. destructor. According to Rosenkranz et al. (2010) there are several factors that can explain the absence of mated daughters; foundresses may die early without producing offspring, they may produce only a male or only females, or may have started egg laying too late to produce mature daughters at the time of emergence The percentage of $A$. $m$. scutellata cells in which only male offspring was produced (9\% drones and 15\% workers) was similar to those reported by Martin and Kryger (2002) and to other honeybee populations studied to date (Table 3). This trait is therefore not likely to be involved in resistance to the mite. In cells with mature daughters, a higher percentage of adult males were either dead or missing in both drone (17\%) and worker (15\%) cells (Table 2) compared to the results of Martin and Kryger (2002) (9\% and 11\%, respectively) in the same population. In surviving Africanised honeybees, adult males died in 13-19\% of cells containing close to emergence workers (Medina and Martin, 1999). Our data show that the percentage of dead males increased in both drone and worker brood compared with measurements of Martin and Kryger (2002) and are similar to those found in surviving populations of Africanised workers (Medina and Martin, 1999). However, European susceptible honeybees also show high proportions of infested cells with no or dead males (mortality rates of $10 \%$ in drone brood and 13-21\% in worker brood; Martin, 1994, 1995a, 2001) and this trait does not appear to be sufficient to decrease mite population growth to levels that 
result in host colony survival. Reasons for the absence of males have been attributed to males either being killed by the pupae during development, or as a result of not being able to find the feeding site made by the foundress (Donzé et al. 1996). Nonetheless, Varroa mite reproductive success is variable since it can be influenced by many factors (e.g. climatic conditions, season, or sub-species of the host; Rosenkranz et al. 2010), and the reproductive values obtained here need to be verified in other savannah honeybee populations. Long-term monitoring of Varroa mite reproduction under South African conditions is also necessary to better understand the interaction between mites, environmental factors and host colony health.

Another factor to consider is the importance of host signals used by Varroa mites for oogenesis activation (Garrido and Rosenkranz, 2004). It is possible that larval signals of certain honeybee populations prevent (Milani et al. 2004) or delay the initiation of the reproductive cycle of the mites, therefore resulting in a decrease in reproductive success (Locke et al. 2012). The family composition observed in our population of A. m. scutellata corresponded with possible reproductive delay in only approximately a third of the cases (data not shown). In the other cases, the composition was more likely due to an interruption or disturbance of the normal reproductive program of the mites as described by Martin (1994, 1995a). The hygienic behaviour of host workers may also lead to an increase in the proportion of infertile mites via the disruption of Varroa mite reproduction and/or the specific removal of fertile mites (Harbo and Harris, 2005; Allsopp, 2006; Harris et al. 2010; Kirrane et al. 2011). The intensity of hygienic behaviour and the role this behaviour may play in colony survival of the savannah honeybee in South Africa is currently being investigated (Strauss et al. unpublished data).

\section{Varroa reproduction in multiply infested drone and worker cells}

The monitoring of reproduction in naturally infested brood allowed us to investigate mite reproduction in cases in which several foundresses invaded the same cell. In this situation, there is more competition for resources and as a result the reproductive success of individual foundresses is usually lower compared to that of singly infested cells (Fuchs and Langenbach, 1989; Eguaras et al. 1994; Martin, 1995b; Mondragón et al. 2006; Kuster et al. 2014). In this study, we also observed a significant decrease in the number of offspring produced per individual foundress between drone cells infested with 1 and 4 or more foundresses, as well as 
between worker cells infested with 1 and 2-3 foundresses. The differences were significant for drones, but not for workers, which may be related to the low number of multiple infestations observed in the latter. The reproductive success (number of mated daughters produced) in drone cells per foundress was higher in cells containing 1 foundress than in cells infested with 2-3 foundresses. However, if we consider the number of mated daughters that emerge from multiply infested drone cells, the output is significantly higher compared to singly infested cells. In singly infested cells there was a high incidence of missing adult males, and as a result daughters could not mate. In contrast, in multiply infested cells where more than one adult male can be produced, daughter mites have a better chance of mating if one or more males remain alive (Martin, 1995b). Indeed, the observed clumped distribution of mites in drone and worker cells could be a mechanism for these mites to deal with the founder effects (Abel et al. 2015) of the relatively new established mite population. Nevertheless, the quantity of sperm a male is able to transfer to one or more daughter mites can be a limiting factor, so even if there are more adult daughters in multiply infested cells, there is a chance that not all of them will get sufficient spermatozoa to ensure reproductive success in the next cycle (Donzé et al. 1996; Wendling et al. 2014).

\section{Mite preference for drone brood}

Varroa mite preference for drone brood has been reported in all honeybee populations studied (Fuchs, 1990; Boot et al. 1995a). This is associated with the fact that the period of maturation of drone brood is longer than that of workers, providing more time for mite reproduction and therefore a higher reproductive success (Boot et al. 1995b; Martin, 1995a; Tribe and Allsopp, 2001). In our study, infestation rates of drone brood were three times that of worker brood, confirming the preference for drones. Despite the longer time available for mites to reproduce on drone brood, the reproductive success of drone infesting mites was a third of that for mites infesting workers. This was linked to higher infertility in singly infested drone cells (52\%) compared to worker cells (30\%). This is in contrast to what has been observed in most other studies that show that infertility in worker brood is similar or higher than in drone brood (Martin et al. 1997 and references therein; Garrido et al. 2003; Calderón et al. 2012). The reasons for this lower reproductive success on drones are not known, but may be related to the high frequency of missing or dead males and immature females. The level of preference measured in A. $\mathrm{m}$. 
scutellata appears lower compared to that of other honeybee populations where the ratio between the sexes' infestation rates ranges from 5-12 (Fries et al. 1994 and references therein; Boot et al. 1995a). The lower preference could be related to the reduced reproductive success measured in our population. However, this ratio has remained the same in the last decade (Martin and Kryger, 2002). Thus, the decrease in mite reproductive success did not result in a decrease in preference for drone brood. Such a relationship may become established over longer evolutionary periods. At present, this phenomenon may constitute a mite trapping mechanism by which the parasites are attracted to individual hosts on which their reproductive success is lower. Such a mechanism could contribute to a decrease in colony infestation rates and an increase in resistance to the parasite.

\section{Resistance rather than tolerance of savannah honeybees towards $V$. destructor}

The A. m. scutellata population studied here shows no conclusive evidence of tolerance towards the effects of infestation by $V$. destructor. Further studies using more precise and standardised methods are needed to allow for more accurate comparisons between susceptible and surviving populations. In contrast, clear evidence for resistance was found in the low fertility, fecundity and reproductive success of Varroa mite foundresses. This low reproduction explains the slow rate at which mite populations grow in savannah honeybee colonies and may constitute the major adaptation allowing for colony survival. The absence of acaricide use in savannah honeybee colonies may have facilitated the development of this resistance by allowing natural selection to take place (Rosenkranz, 1999). What we may be witnessing is the establishment of a stable hostparasite relationship where the reduced negative effects of mite infestation result in a level of damage that can be tolerated at the colony level. This is supported by the fact that since the last assessment of Varroa mite reproduction in the savannah honeybee, infertility rates measured in this study have increased and fecundity rates as well as reproductive success decreased (Martin and Kryger, 2002). Similar observations of tolerance or resistance development over time in the absence of treatment have been observed in other honeybee populations invaded by Varroa mites

(De Jong and Soares, 1997; Kefuss et al. 2004; Fries et al. 2006; Le Conte et al. 2007; Seeley 2007; Locke and Fries, 2011; Locke et al. 2012; Seeley et al. 2015). These studies show a variety of mechanisms leading to colony survival and their identification provides us with an 
array of traits that can be selectively bred into susceptible honeybee populations to increase their survival to infestations by this most damaging parasite.

Nevertheless, a more detailed understanding is needed in order to identify all the possible behaviours of the savannah honeybee from South Africa (e.g. hygienic and grooming behaviour, swarming frequency) that may contribute to keeping mite numbers low and consequently reducing and/or preventing mite population growth above the damage threshold for the colony.

\section{ACKNOWLEDGEMENTS}

We thank Kendall Richardson for assistance in the field and laboratory. We are grateful to three reviewers for constructive comments on the manuscript.

\section{FINANCIAL SUPPORT}

The financial assistance of the National Research Foundation (NRF) and the University of Pretoria towards this research is hereby acknowledged. Agroscope is acknowledged for providing travel funds for VD. Opinions expressed and conclusions arrived at, are those of the authors and are not necessarily to be attributed to the NRF.

\section{REFERENCES}

Abel, S., Abel zur Wiesch, P., Davis, B. M. and Waldor, M. K. (2015). Analysis of bottlenecks in experimental models of infection. PLoS Pathogens 11, e1004823. doi: 10.1371/journal.ppat.1004823.

Alaux, C., Dantec, C., Parrinello, H. and Le Conte, Y. (2011). Nutrigenomics in honey bees: digital gene expression analysis of pollen's nutritive effects on healthy and varroa-parasitized bees. Genomics 12, 496. doi: 10.1186/1471-2164-12-496.

Allsopp, M. H. (1997). Varroa jacobsoni in South Africa. South African Bee Journal 69, 73-82.

Allsopp, M. H. (2006). Analysis of Varroa destructor infestation of southern African honeybee populations. MSc-thesis, University of Pretoria, Pretoria, South Africa. 
Amdam, G. V., Hartfelder, K., Norberg, K., Hagen, A. and Omholt, S. W. (2004). Altered physiology in worker honey bees (Hymenoptera: Apidae) infested with the mite Varroa destructor (Acari: Varroidae): A factor in colony loss during overwintering? Journal of Economic Entomology $\quad$ 97, $\quad 741-747 . \quad$ doi: $\quad 10.1603 / 0022-$ 0493(2004)097[0741:APIWHB]2.0.CO;2.

Annoscia, D., Del Piccolo, F. and Nazzi, F. (2012). How does the mite Varroa destructor kill the honeybee Apis mellifera? Alteration of cuticular hydrocarbons and water loss in infested honeybees. Journal of Insect Physiology 58, 1548-1555. doi: 10.1016/j.jinsphys.2012.09.008.

Aronstein, K. A., Saldivar, E., Vega, R., Westmiller, S. and Douglas, A. E. (2012). How Varroa parasitism affects the immunological and nutritional status of the honey bee, Apis mellifera. Insects 3, 601-615. doi: 10.3390/insects3030601.

Boot, W. J., Schoenmaker, J., Calis, J. N. M. and Beetsma, J. (1995a). Invasion of Varroa jacobsoni into drone brood cells of the honey bee, Apis mellifera. Apidologie 26, 109-118. doi: 10.1051/apido:19950204.

Boot, W. J., van Baalen, M. and Sabelis, M. W. (1995b). Why do Varroa mites invade worker brood cells of the honey bee despite lower reproductive success? Behavioral Ecology and Sociobiology 36, 283-289. doi: 10.1007/BF00165837.

Bowen-Walker, P. L. and Gunn, A. (2001). The effect of the ectoparasitic mite, Varroa destructor on adult worker honeybee (Apis mellifera) emergence weights, water, protein, carbohydrate, and lipid levels. Entomologia Experimentalis et Applicata 101, 207-217. doi: 10.1046/j.1570-7458.2001.00905.x. 
Bradford, M. M. (1976). A rapid and sensitive method for the quantitation of microgram quantities of protein utilizing the principle of protein-dye binding. Analytical Biochemistry $\mathbf{7 2 ,}$ 248-254.

Calderón, R. A., Ureña, S. and van Veen, J. W. (2012). Reproduction of Varroa destructor and offspring mortality in worker and drone brood cells of Africanized honey bees. Experimental and Applied Acarology 56, 297-307. doi: 10.1007/s10493-012-9518-0.

Carneiro, F. E., Torres, R. R., Strapazzon, R., Ramirez, S. A., Guerra, J. C. V., Koling, D. F. and Moretto, G. (2007). Changes in the reproductive ability of the mite Varroa destructor (Anderson and Trueman) in Africanized honey bees (Apis mellifera L.) (Hymenoptera: Apidae) colonies in southern Brazil. Neotropical Entomology 36, 949-952. doi: 10.1590/S1519566X2007000600018.

Contzen, C., Garedew, A., Lamprecht, I. and Schmolz, E. (2004). Calorimetrical and biochemical investigations on the influence of the parasitic mite Varroa destructor on the development of honeybee brood. Thermochimica Acta 415, 115-121. doi: 10.1016/j.tca.2003.06.006.

De Jong, D. and De Jong, P. H. (1983). Longevity of Africanized honey bees (Hymenoptera: Apidae) infested by Varroa jacobsoni (Parasitiformes: Varroidae). Journal of Economic Entomology 76, 766-768.

De Jong, D. and Soares, A. E. E. (1997). An isolated population of Italian bees that has survived Varroa jacobsoni infestation without treatment for over 12 years. American Bee Journal 137, 742-747. 
De Jong, D., De Jong, P. H. and Gonçalves, L. S. (1982). Weight loss and other damage to developing worker honeybees from infestation with Varroa jacobsoni. Journal of Apicultural Research 21, 165-167.

de Miranda, J. R. and Genersch, E. (2010). Deformed wing virus. Journal of Invertebrate Pathology 103, 48-61. doi: 10.1016/j.jip.2009.06.012.

de Miranda, J. R., Bailey, L., Ball, B. V., Blanchard, P., Budge, G. E., Chejanovsky, N., Chen, Y-P., Gauthier, L., Genersch, E., de Graaf, D. C., Ribière, M., Ryabov, E., De Smet, L. and van der Steen, J. J. M. (2013). Standard methods for virus research in Apis mellifera. In The COLOSS BEEBOOK, Volume II: standard methods for Apis mellifera pest and pathogen research (ed Dietemann, V., Ellis, J.D. and Neumann, P.), Journal of Apicultural Research 52, doi: 10.3896/IBRA.1.52.4.22.

Dietemann, V., Nazzi, F., Martin, S. J., Anderson, D. L., Locke, B., Delaplane, K. S., Wauquiez, Q., Tannahill, C., Frey, E., Ziegelmann, B., Rosenkranz, P. and Ellis, J. D. (2013). Standard methods for varroa research. In The COLOSS BEEBOOK, Volume II: standard methods for Apis mellifera pest and pathogen research (ed Dietemann, V., Ellis, J.D. and Neumann, P.), Journal of Apicultural Research 52, doi: 10.3896/IBRA.1.52.1.09.

Dietemann, V., Pflugfelder, J., Anderson, D., Charrière, J. D., Chejanovsky, N., Dainat, B., de Miranda, J. R., Delaplane, K., Dillier, F. X., Fuchs, S., Gallmann, P., Gauthier, L., Imdorf, A., Koeniger, N., Kralj, J., Meikle, W., Pettis, J., Rosenkranz, P., Sammataro, D., Smith, D., Yañez, O. and Neumann, P. (2012). Varroa destructor: research avenues towards sustainable control. Journal of Apicultural Research 51, 125-132. doi: 10.3896/IBRA.1.51.1.15.

Dietemann, V., Pirk, C. W. W. and Crewe, R. M. (2009). Is there a need for conservation of honeybees in Africa? Apidologie 40, 285-295. doi: 10.1051/apido/2009013. 
Donzé, G. and Guerin, P. M. (1994). Behavioral attributes and parental care of Varroa mites parasitizing honeybee brood. Behavioral Ecology and Sociobiology 34, 305-319. doi: 10.1007/BF00197001.

Donzé, G., Herrmann, M., Bachofen, B. and Guerin, P. M. (1996). Effect of mating frequency and brood cell infestation rate on the reproductive success of the honeybee parasite Varroa jacobsoni. Ecological Entomology 21, 17-26. doi: 10.1111/j.1365-2311.1996.tb00261.x.

Duay, P. (2002). Relation between the level of preimaginal infestation by the brood mite Varroa destructor and adult life expectancy in drone honeybees (Hymenoptera: Apidae: Apis mellifera). Entomologia Generalis 26, 213-218.

Duay, P., De Jong, D. and Engels, W. (2002). Decreased flight performance and sperm production in drones of the honey bee (Apis mellifera) slightly infested by Varroa destructor mites during pupal development. Genetics and Molecular Research 1, 227-232.

Duay, P., De Jong, D. and Engels, W. (2003). Weight loss in drone pupae (Apis mellifera) multiply infested by Varroa destructor mites. Apidologie 34, 61-65. doi: 10.1051/apido:2002052.

Eguaras, M., Marcangeli, J. and Fernandez, N. A. (1994). Influence of 'parasitic intensity' on Varroa jacobsoni Oud reproduction. Journal of Apicultural Research 33, 155-159.

Fletcher, D. J. C. (1978). The African bee, Apis mellifera adansonii, in Africa. Annual Review of Entomology 23, 151-171. doi: 10.1146/annurev.en.23.010178.001055.

Frey, E., Odemer, R., Blum, T. and Rosenkranz, P. (2013). Activation and interruption of the reproduction of Varroa destructor is triggered by host signals (Apis mellifera). Journal of Invertebrate Pathology 113, 56-62. doi: 10.1016/j.jip.2013.01.007. 
Fries, I., Camazine, S. and Sneyd, J. (1994). Population dynamics of Varroa jacobsoni: a model and a review. Bee World 75, 5-28.

Fries, I., Imdorf, A. and Rosenkranz, P. (2006). Survival of mite infested (Varroa destructor) honey bee (Apis mellifera) colonies in a Nordic climate. Apidologie 37, 564-570. doi: 10.1051/apido:2006031.

Fuchs, S. (1990). Preference for drone brood cells by Varroa jacobsoni Oud in colonies of Apis mellifera carnica. Apidologie 21, 193-199. doi: 10.1051/apido:19900304.

Fuchs, S. and Langenbach, K. (1989). Multiple infestation of Apis mellifera L. brood cells and reproduction in Varroa jacobsoni Oud. Apidologie 20, 257-266. doi: 10.1051/apido:19890308.

Garrido, C. and Rosenkranz, P. (2004). Volatiles of the honey bee larva initiate oogenesis in the parasitic mite Varroa destructor. Chemoecology 14, 193-197. doi: 10.1007/s00049-0040278-0.

Garrido, C., Rosenkranz, P., Paxton, R. J. and Gonçalves, L. S. (2003). Temporal changes in Varroa destructor fertility and haplotype in Brazil. Apidologie 34, 535-541. doi: 10.1051/apido:2003041.

Gisder, S., Aumeier, P. and Genersch, E. (2009). Deformed wing virus (DWV): viral load and replication in mites (Varroa destructor). Journal of General Virology 90, 463-467. doi: 10.1099/vir.0.005579-0.

Glinski, Z. and Jarosz, J. (1984). Alterations in haemolymph proteins of drone honey bee larvae parasitised by Varroa jacobsoni. Apidologie 15, 329-338. doi: 10.1051/apido:19840305.

Glinski, Z. and Jarosz, J. (1992). Varroa jacobsoni as a carrier of bacterial infections to a recipient bee host. Apidologie 23, 25-31. doi: 10.1051/apido:19920103. 
Harbo, J. R. and Harris, J. W. (2005). Suppressed mite reproduction explained by the behaviour of adult bees. Journal of Apicultural Research 44, 21-23.

Harris, J. W., Danka, R. G. and Villa, J. D. (2010). Honey bees (Hymenoptera: Apidae) with the trait of varroa sensitive hygiene remove brood with all reproductive stages of varroa mites (Mesostigmata: Varroidae). Annals of the Entomological Society of America 103, 146-152. doi: 10.1603/AN09138.

Hrassnigg, N. and Crailsheim, K. (2005). Differences in drone and worker physiology in honeybees. Apidologie 36, 255-277. doi: 10.1051/apido:2005015.

Human, H., Archer, C. R., du Rand, E. E., Pirk, C. W. W. and Nicolson, S. W. (2014). Resistance of developing honeybee larvae during chronic exposure to dietary nicotine. Journal of Insect Physiology 69, 74-79. doi: 10.1016/j.jinsphys.2014.03.012.

Jandricic, S. E. and Otis, G. W. (2003). The potential for using male selection in breeding honey bees resistant to Varroa destructor. Bee World 84, 155-164.

Jarolimek, J. P. and Otis, G. W. (2001). A comparison of fitness components in large and small honeybee drones. American Bee Journal 12, 891-892.

Kefuss, J., Vanpouke, J., De Lahitte, J. D. and Ritter, W. (2004). Varroa tolerance in France of Intermissa bees from Tunisia and their naturally mated descendants: 1993-2004. American Bee Journal 144, 563-568.

Kirrane, M. J., de Guzman, L. I., Rinderer, T. E., Frake, A. M., Wagnitz, J. and Whelan, P. M. (2011). Asynchronous development of honey bee host and Varroa destructor (Mesostigmata: Varroidae) influences reproductive potential of mites. Journal of Economic Entomology 104, 1146-1152. doi: 10.1603/EC11035. 
Kralj, J. and Fuchs, S. (2006). Parasitic Varroa destructor mites influence flight duration and homing ability of infested Apis mellifera foragers. Apidologie 37, 577-587. doi: 10.1051/apido:2006040.

Kuster, R. D., Boncristiani, H. F. and Rueppell, O. (2014). Immunogene and viral transcript dynamics during parasitic Varroa destructor mite infection of developing honey bee (Apis mellifera) pupae. The Journal of Experimental Biology 217, 1710-1718. doi: 10.1242/jeb.097766.

Le Conte, Y., de Vaublanc, G., Crauser, D., Jeanne, F., Rousselle, J-C. and Bécard, J-M. (2007). Honey bee colonies that have survived Varroa destructor. Apidologie 38, 566-572. doi: 10.1051/apido:2007040.

Liu, T. (1996). Varroa mites as carriers of honey bee Chalkbrood. American Bee Journal 136, 655-655.

Locke, B. and Fries, I. (2011). Characteristics of honey bee colonies (Apis mellifera) in Sweden surviving Varroa destructor infestation. Apidologie 42, 533-542. doi: 10.1007/s13592-011-00295.

Locke, B., Le Conte, Y., Crauser, D. and Fries, I. (2012). Host adaptations reduce the reproductive success of Varroa destructor in two distinct European honey bee populations. Ecology and Evolution 2, 1144-1150. doi: 10.1002/ece3.248.

Marcangeli, J., Monetti, L. and Fernandez, N. (1992). Malformations produced by $V$. jacobsoni on Apis mellifera in the province of Buenos Aires, Argentina. Apidologie 23, 399-402. Martin, S. J. (1994). Ontogenesis of the mite Varroa jacobsoni Oud. in worker brood of the honeybee Apis mellifera L. under natural conditions. Experimental and Applied Acarology 18, 87-100. doi: 10.1007/BF00055033. 
Martin, S. J. (1995a). Ontogenesis of the mite Varroa jacobsoni Oud. in drone brood of the honeybee Apis mellifera L. under natural conditions. Experimental and Applied Acarology 19, 199-210. doi: 10.1007/BF00130823.

Martin, S. J. (1995b). Reproduction of Varroa jacobsoni in cells of Apis mellifera containing one or more mother mites and the distribution of these cells. Journal of Apicultural Research 34, 187-196.

Martin, S. J. (2001). Varroa destructor reproduction during the winter in Apis mellifera colonies in UK. Experimental and Applied Acarology 25, 321-325. doi: 10.1023/A:1017943824777.

Martin, S. J. and Kryger, P. (2002). Reproduction of Varroa destructor in South African honey bees: does cell space influence Varroa male survivorship? Apidologie 33, 51-61. doi: 10.1051/apido: 2001007.

Martin, S. J., Holland, K. and Murray, M. (1997). Non-reproduction in the honeybee mite Varroa jacobsoni. Experimental and Applied Acarology 21, 539-549. doi: 10.1023/A:1018492231639.

McMenamin, A. J. and Genersch, E. (2015). Honey bee colony losses and associated viruses. Current Opinion in Insect Science 8, 121-129. doi: 10.1016/j.cois.2015.01.015.

Medina, L. M. and Martin, S. J. (1999). A comparative study of Varroa jacobsoni reproduction in worker cells of honey bees (Apis mellifera) in England and Africanized bees in Yucatan, Mexico. Experimental and Applied Acarology 23, 659-667. doi: 10.1023/A:1006275525463.

Milani, N., Della Vedova, G. and Nazzi, F. (2004). (Z)-8-Heptadecene reduces the reproduction of Varroa destructor in brood cells. Apidologie 35, 265-273. doi: 10.1051/apido:2003064. 
Mondragón, L., Martin, S. J. and Vandame, R. (2006). Mortality of mite offspring: a major component of Varroa destructor resistance in a population of Africanized bees. Apidologie 37, 67-74. doi: 10.1051/apido:2005053.

Moritz, R. F. A. (1985). Heritability of the postcapping stage in Apis mellifera and its relation to varroatosis resistance. The Journal of Heredity 76, 267-270.

Moritz, R. F. A. and Mautz, D. (1990). Development of Varroa jacobsoni in colonies of Apis mellifera capensis and Apis mellifera carnica. Apidologie 21, 53-58. doi: 10.1051/apido:19900107.

Pinto, F. A., Souza, G. K., Sanches, M. A. and Serrão, J. E. (2011). Parasitic effects of Varroa destructor (Acari: Varroidae) on hypopharyngeal glands of Africanized Apis mellifera (Hymenoptera: Apidae). Sociobiology 58, 769-778.

Pirk, C. W. W., Human, H., Crewe, R. M. and vanEngelsdorp, D. (2014). A survey of managed honey bee colony losses in the Republic of South Africa - 2009 to 2011. Journal of Apicultural Research 53, 35-42. doi: 10.3896/IBRA.1.53.1.03.

Råberg, L., Graham, A. L. and Read, A. F. (2009). Decomposing health: tolerance and resistance to parasites in animals. Philosophical Transactions of the Royal Society B: Biological Sciences 364, 37-49. doi: 10.1098/rstb.2008.0184.

Råberg, L., Sim, D. and Read, A. F. (2007). Disentangling genetic variation for resistance and tolerance to infectious diseases in animals. Science 318, 812-814. doi: 10.1126/science.1148526. Ritter, W. (1993). New results of the development of tolerance to Varroa jacobsoni in bee colonies in Tunisia. In Asian apiculture (ed. Connor, L. J., Rinderer, T. E., Sylvester, H. A. and Wongsiri, S.), pp. 463-467. Wicwas Press, Cheshire, USA. 
Rosenkranz, P. (1999). Honey bee (Apis mellifera L.) tolerance to Varroa jacobsoni Oud. in South America. Apidologie 30, 159-172. doi: 10.1051/apido:19990206.

Rosenkranz, P. and Engels, W. (1994). Infertility of Varroa jacobsoni females after invasion into Apis mellifera worker brood as a tolerance factor against varroatosis. Apidologie 25, 402411. doi: 10.1051/apido:19940407.

Rosenkranz, P., Aumeier, P. and Ziegelmann, B. (2010). Biology and control of Varroa destructor. Journal of Invertebrate Pathology 103, 96-119. doi: 10.1016/j.jip.2009.07.016.

Ruttner, F. and Marx, G. (1984). Observation about a possible adaptation of Varroa jacobsoni to Apis mellifera L. in Uruguay. Apidologie 15, 43-62.

Schlüns, H., Schlüns, E. A., van Praagh, J. and Moritz, R. F. A. (2003). Sperm numbers in drone honeybees (Apis mellifera) depend on body size. Apidologie 34, 577-584. doi: 10.1051/apido:2003051.

Schneider, P. and Drescher, W. (1987). Einfluss der Parasitierung durch die Milbe Varroa jacobsoni Oud auf das Schlupfgewicht, die Gewichtsentwicklung, die Entwicklung der Hypopharynxdrüsen und die Lebensdauer von Apis mellifera L. Apidologie 18, 101-110. doi: 10.1051/apido:19870108.

Seeley, T. D. (2007). Honey bees of the Arnot Forest: a population of feral colonies persisting with Varroa destructor in the northeastern United States. Apidologie 38, 19-29. doi: 10.1051/apido:2006055.

Seeley, T. D., Tarpy, D. R., Griffin, S. R., Carcione, A. and Delaney, D. A. (2015). A survivor population of wild colonies of European honeybees in the northeastern United States: investigating its genetic structure. Apidologie 46, 654-666. doi: 10.1007/s13592-015-0355-0. 
Strauss, U., Human, H., Gauthier, L., Crewe, R. M., Dietemann, V. and Pirk, C. W. W. (2013). Seasonal prevalence of pathogens and parasites in the savannah honeybee (Apis mellifera scutellata). Journal of Invertebrate Pathology 114, 45-52. doi: 10.1016/j.jip.2013.05.003.

Strauss, U., Pirk, C. W. W., Crewe, R. M., Human, H. and Dietemann, V. (2015). Impact of Varroa destructor on honeybee (Apis mellifera scutellata) colony development in South Africa. Experimental and Applied Acarology 65, 89-106. doi: 10.1007/s10493-014-9842-7.

Strick, H. and Madel, G. (1988). Transmission of the pathogenic bacterium Hafnia alvei to honey bees by the ectoparasitic mite Varroa jacobsoni. In Africanized honey bees and bee mites (ed. Needham, G. R., Page, R. E., Delfinado-Baker, M. and Bowman, C. E.), pp. 462-466. Ellis Horwood Limited, Chichester, UK.

Tribe, G. D., Allsopp, M. H. (2001). Life history of the honeybee colony. In Beekeeping in South Africa (ed. Johannsmeier, M. F.), pp. 17-26. Plant Protection Handbook No. 14, Agricultural Research Council, Pretoria.

van Dooremalen, C., Gerritsen, L., Cornelissen, B., van der Steen, J. J. M., van Langevelde, F. and Blacquière, T. (2012). Winter survival of individual honey bees and honey bee colonies depends on level of Varroa destructor infestation. PLoS ONE 7, e36285. doi: 10.1371/journal.pone.0036285.

van Dooremalen, C., Stam, E., Gerritsen, L., Cornelissen, B., van der Steen, J. J. M., van Langevelde, F. and Blacquière, T. (2013). Interactive effect of reduced pollen availability and Varroa destructor infestation limits growth and protein content of young honey bees. Journal of Insect Physiology 59, 487-493. doi: 10.1016/j.jinsphys.2013.02.006.

Wallberg, A., Han, F., Wellhagen, G., Dahle, B., Kawata, M., Haddad, N., Simões, Z. L. P., Allsopp, M. H., Kandemir, I., De la Rúa, P., Pirk, C. W. W. and Webster, M. T. (2014). A 
worldwide survey of genome sequence variation provides insight into the evolutionary history of the honeybee Apis mellifera. Nature Genetics 46, 1081-1088. doi: 10.138/ng.3077.

Weinberg, K. P. and Madel, G. (1985). The influence of the mite Varroa jacobsoni Oud. on the protein concentration and the haemolymph volume of the brood of worker bees and drones of the honey bee Apis mellifera L. Apidologie 16, 421-436. doi: 10.1051/apido:19850407.

Wendling, S., Guillet, B., Roy, L., Kreiter, S. and Colin, M-E. (2014). Fertilization and fertility in the female of Varroa destructor, a key point for the parasite population dynamics. Apidologie 45, 722-732. doi: 10.1007/s13592-014-0291-4.

Yang, X. and Cox-Foster, D. (2007). Effects of parasitization by Varroa destructor on survivorship and physiological traits of Apis mellifera in correlation with viral incidence and microbial challenge. Parasitology 134, 405-412. doi: 10.1017/S0031182006000710.

Zioni, N., Soroker, V. and Chejanovsky, N. (2011). Replication of Varroa destructor virus 1 (VDV-1) and a Varroa destructor virus 1-deformed wing virus recombinant (VDV-1-DWV) in the head of the honey bee. Virology 417, 106-112. doi: 10.1016/j.virol.2011.05.009.

Żóltowska, K., Lipiński, Z. and Dmitryjuk, M. (2005). The total protein content, protein fractions and proteases activities of drone prepupae of Apis mellifera due to varrosis. Wiadomooeci Parazytologiczne 51, 39-43. 